\title{
Searching for mechanism of correlation of interests of the transport holding's managers and employees
}

\author{
Natalia Chevtaeva ${ }^{1}$, Olga Shestopalova $^{2}$, and Tatyana Okuneva ${ }^{2, *}$ \\ ${ }^{1}$ Ural Institute of Management, branch of the Russian Presidential Academy of National Economy \\ and Public Administration, 8 March str., 66, 620144 Ekaterinburg, Russia \\ ${ }^{2}$ Ural State University of Railway Transport, Kolmogorova str., 66, 620034 Ekaterinburg, Russia
}

\begin{abstract}
Digital transformation is the current development paradigm of any modern organisation. Digitalisation, automation and robotisation actively affect the activities of both large and small enterprises and have an impact on all spheres of life. Studying the correlation of corporate interests of employees and managers of Russian Railways, JSC transport holding allowed us to identify areas of their correlation, as well as areas where we defined their inconsistency. At the same time, this area of interaction between employees and employers requires active research since it does not always fall into the research field. Based on empirical research, analysis of corporate reports on the company's business activities, as well as content analysis of interviews with managers, the authors show that alignment of interest can be achieved by means of systematic development and meeting the needs of staff in training and development; availability of a clear program of the company's development and provision of a wide range of social benefits and guarantees contribute to the achievement of stable position on the market of logistic services, stable work teams, high level of staff involvement in the activities of the company, higher job satisfaction, greater confidence of staff in developing and implementing changes, as well as improving technical, technological and operating processes. On the other hand, the study shows that in the opinion of managers and potential employees (based on the analysis of the generation Z's system of values) the corporate management model of Russian Railways, JSC may create barriers to the development of the company and fulfilment of employees' labour potential. This problem can be avoided by improving corporate management systems and increasing the independence of the staff.
\end{abstract}

\section{Introduction}

Dynamic changes that are associated with modern trends of digitalisation, automation and robotisation and determine the transformation of all spheres of life, cannot but affect current relations between employees and employers. Such transformations are especially

\footnotetext{
*Corresponding author: tat-okuneva@list.ru
} 
reflected in the activities of large organisations where the interests of various stakeholders such as employees, company managers, business owners, partners, and clients, may come into conflict[1]. In general, organisations, including large ones, where these trends are particularly acute due to the need to maintain competitiveness, are interested in meeting contemporary social and economic requirements, implementing technical and technological changes, and developing personnel. At the same time, employees strive to ensure a steady job and a comfortable workplace. The environment contributes to the employee-employer relationship in the form of such global trends as work-life balance, self-fulfilment in the profession, and opportunities to influence the administrative reality. As for the companies, they announce such trends as an increase of involvement, staff planning, social protection of employees, and well-being as part of work [2]. In this situation of conflict between the requirements of the external environment, the needs of employees and the interests of the company, the search for mechanisms for their coordination, through which each of the parties will be able to achieve its goals in constantly changing and unpredictable circumstances, is of particular importance.

\section{Literature Review}

The common trend of digitalisation, robotisation and automation of work processes, which was declared and supported by world leaders in connection with the announced achievement of Industry 4.0 by advanced economies, is studied in relation to such sectors as industry, finance, and services and has been described by many researchers. $[3,4]$

They pay a lot of attention to the transport industry [5] and its modernisation in the light of these trends.

At the same time, as part of the study of corporate governance issues, researchers most often consider the alignment of corporate interests of companies and groups of stakeholders, especially partners and clients. [6, 7, 8, 9] The problems of interaction between employees and managers are also studied, but most often they are considered from the position of forming favourable relations for work, changes on the labour market, transformation of employment conditions for employees [10, 11], and creating a social and psychological climate and a comfortable environment. [12]

In our opinion, the issues of correlation of interests of employers and employees have not been sufficiently studied, which allowed us to determine the purpose of the study: to identify areas of correlation and inconsistency of interests of managers and employees in achieving the strategic objectives of the transport holding, as well as to search for mechanisms for their coordination.

This goal allowed us to define the following research problems:

1. To identify the area of correlation of interests of the transport holding company and the main groups of stakeholders, specifically the correlation of interests of employers and employees

2. To identify the area of the inconsistency of corporate interests and suggest possible mechanisms for their coordination taking into account the current trends of transport, industrial, social and economic development.

\section{Materials and Methods}

The interconnection of the relationship between employees, company, and environment has a systemic and fundamental nature and determines the structure of interaction between these interests during the transformation of technology, as well as the position of the individual as an employee and a member of the social environment. The company's 
activities in the field of meeting its operational and tactical interests lie in the zone of implementation of adaptive potential while its strategic interests lie in the zone of the company's innovative potential.

The indicators for implementation of adaptive potential are the existence of sound policies for the development and introduction of innovations; monitoring operative, technical, social and economic indicators; wage level, staff stability and turnover; availability of social guarantees; and level of job satisfaction of the company's employees.

Skill improvement, training and staff development can be considered as a way to guarantee jobs under the changing working conditions and adapt the qualification level of personnel in accordance with the requirements of the production, as well as to create opportunities for employees to grow professionally, identify workplace issues and offer solutions for them thereby changing the technical, technological, social and economic conditions and revealing innovative potential.

In order to implement the innovative potential, the company should ensure conditions under which employees can receive timely information about the strategy and tactics of the company's activities, should create opportunities for development and implementation of innovative projects in its activities and support innovators. The presence of such platforms, as well as the desire and active participation of initiative workers in innovative activities, are the indicators of the implementation of the innovative potential.

The object of our research is employees and managers of Russian Railways, JSC in the conditions of technical and technological changes. The purpose of the study is to determine the priorities of the company's development as a leading employer and leader of the transport industry in the Ural region, to consider whether the employees' system of values and needs correspond to the main approaches and principles of the corporate management.

The research methodology involved analysis of the company's corporate social responsibility reports, other publications, analytical materials and reviews of its activities in the corporate publications, as well as interviewing employees of Russian Railways to identify their system of values, attitudes to work, and professional preferences.

Information sampling for the study was done by selecting articles that include interviews with managers and leading specialists of the holding published in The HRPartner. Vremya. Vyzovy. Resheniya (HR-Partner. Time. Challenges. Solutions) and The Pult Upravleniya (Control Board) magazines, The Gudok (Whistle) and The Uralskaya Magistral (Ural Highway) newspapers from 2014 to 2020 (included 126 publications) and data from the reports of Russian Railways on its activities in the field of sustainable development for the period from 2016 to 2019 [13]

According to the company's corporate reports, we ensured that representatives of various categories of employees (managers, white-collar and blue-collar workers) were present in the sample (Table 1). Since there is no official information regarding the region, we were guided by the ratios that are typical for the company as a whole.

Table 1. Characteristics of the sampled interviewed employees of the transport holding

\begin{tabular}{|l|c|c|c|}
\hline & $\begin{array}{c}\text { Managers, } \\
\%\end{array}$ & $\begin{array}{c}\text { White- } \\
\text { collar workers, \% }\end{array}$ & $\begin{array}{c}\text { Blue-collar } \\
\text { workers, \% }\end{array}$ \\
\hline \multicolumn{3}{|c|}{2016} & 29.1 \\
\hline $\begin{array}{l}\text { Total for the company (N=774.0 thousand } \\
\text { people) }\end{array}$ & 7.6 & 33.4 & 58.3 \\
\hline Representation in the sample (N=768 people) & 7.9 & 29.2 & 63.1 \\
\hline $\begin{array}{l}\text { Total for the company (N=743.1 thousand } \\
\text { people) }\end{array}$ & 7.7 & 34.6 & 56.7 \\
\hline Representation in the sample (N=856 people) & 8.7 & \\
\hline
\end{tabular}


We ensured that employees from different types of cities where the company has its structural divisions were presented in the sample (Table 2).

Table 2. Territorial distribution of respondents by cities of the company's presence

\begin{tabular}{|l|l|c|c|}
\hline $\begin{array}{l}\text { Types of cities in the } \\
\text { Sverdlovsk region }\end{array}$ & $\begin{array}{l}\text { Cities of the } \\
\text { Sverdlovsk region }\end{array}$ & \multicolumn{2}{|c|}{$\begin{array}{r}\text { Territorial distribution of respondents (people } \\
/ \% \text { of the total number of respondents) }\end{array}$} \\
\cline { 3 - 4 } & & 2016 & 2019 \\
\hline Million-plus city & Ekaterinburg & $278 / 36.2$ & $318 / 37.1$ \\
\hline \multirow{3}{*}{ Major city } & Nizhny Tagil & $78 / 10.2$ & $84 / 9.8$ \\
\cline { 2 - 4 } & Tyumen & $71 / 9.3$ & $86 / 10.1$ \\
\cline { 2 - 4 } & Chelyabinsk & $67 / 8.7$ & $71 / 8.3$ \\
\hline \multirow{2}{*}{ Large city } & Kamensk-Uralsky & $61 / 7.9$ & $81 / 9.5$ \\
\cline { 2 - 4 } & Kurgan & $58 / 7.5$ & $58 / 6.8$ \\
\hline \multirow{2}{*}{ Medium-sized city } & Serov & $63 / 8.2$ & $57 / 6.7$ \\
\cline { 2 - 4 } & Shadrinsk & $52 / 5.2$ & $54 / 6.3$ \\
\hline Small city & Alapaevsk & $40 / 6.8$ & $86 / 5.4$ \\
\hline Total & & $768 / 100 \%$ & $856 / 100 \%$ \\
\hline
\end{tabular}

\section{Results and Discussion}

In our opinion, in its activities, the company primarily implements its adaptive potential which allows it to maintain and keep its position and at the same time, take into account the trends of technical, technological, social and economic development. This is the area of relations between employees and the company where the corporate interest correlate.

The company developed and approved the Strategy of Railway Transport Development in the Russian Federation until 2030, Long-term Development Program of RZD, JSC until 2025, and the Strategy of Digital Transformation of RZD, JSC. In particular, the company has defined 11 areas of development that describe technological and technical innovations in the transportation process, customer digital services, etc. These strategies are supplemented by the result-based monitoring system and offer an opportunity to improve the innovation activities. Such projects as New Link, Leader of Changes, and Meeting of Youth of Russian Railways offer competitions the purpose of which is to develop engineering and technical potential and involve young people in solving corporate problems and innovative development. [13, p. 153-155] Such projects help to overcome some of the limitations of the Single Corporate Competencies Model adopted in May 2019, which sets clear but limited requirements for the competencies of employees at various hierarchical levels. 'First, we show what an employee should strive for so that the company could achieve its goals - this is the first step. Then we say how to achieve these goals - this is the second step. And the third step is the key qualities that an employee needs today.' (D. Shakhanov, 2019)

Such systematic activity results in the company's leading position as a cargo carrier (market share of $87,2 \%$ ), as well as a socially significant provider of passenger transportation services (they account for $23.4 \%$ ), although in this segment the primacy remains with air transport $(56.6 \%)$. The following data show that management directs its attention to mobility and flexibility with a focus on retaining staff: the company has a consistently low level of staff turnover (7.5\% in 2016 and $6.7 \%$ in 2019 ), a large per cent of young employees (39.8\% under the age of 35 and $39.4 \%$ aged $36-45)$, while more than half of employees have 5-10 years of experience or more. The salary of employees is competitive and indexed annually; the holding is in the $23 \mathrm{rd}$ position among 88 main economic activities, and at the end of 2019, the salary of employees of the company was by $22 \%$ higher than the average salary in the country. [13] 
Russian Railways, JSC implements a number of projects committed to the social welfare of its employees and their families and provision of medical services for employees and passengers, supports sports and culture and implements programs to support working and non-working pensioners, etc. According to the Russian Public Opinion Research Center, Russians named the company among the three most desirable places to work for. As it was accurately noted in one of the interviews, 'If we compare the infrastructure today and, let say, ten years ago, these are two different railways. We managed to achieve high performance and technological results thanks to the stability of our team.' (A. Lesun, 2019).

A survey of the holding's employees in the Ural region showed a high level of employee satisfaction. 28.4\% of employees of the holding estimated their income at the level of "High" and "Very high", the overwhelming number of respondents (76.4 in 2016 and 78.2 in 2019) noted that they liked their current job, and if they had such an opportunity, less than a quarter of the surveyed employees would leave their jobs $(22,5$ in 2016 and 19,3 in 2019).

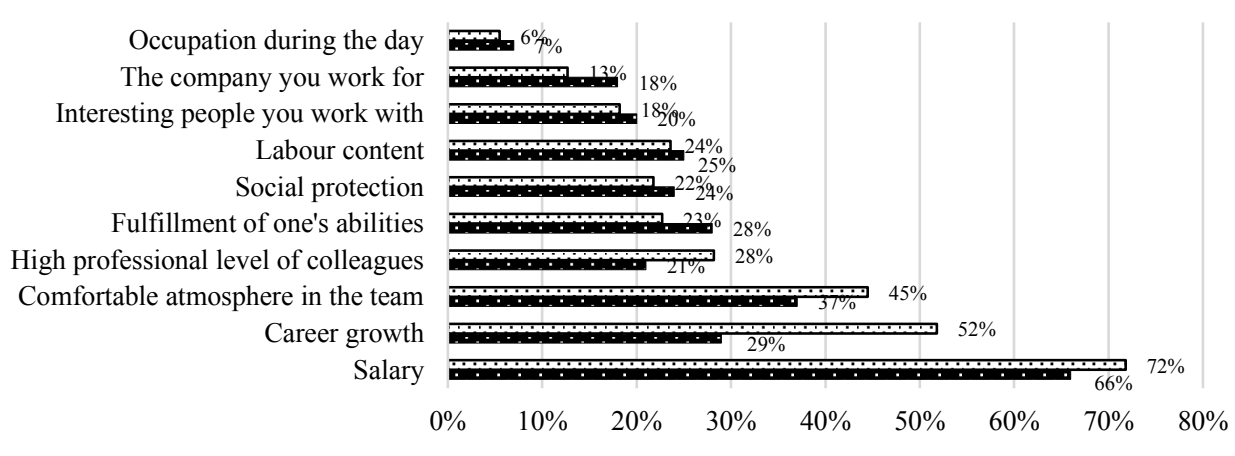

๑Transport holding's employees, 2019

- Transport holding's employees, 2016

Fig. 1. Distribution of responses to the question "What is most important for you in your work?", \% of the number of respondents

In 2019, compared to 2016, the importance of such factors as "Fulfilment of one's abilities", "Social protection", "Labour content" and a number of other factors decreased (Figure 1). We attribute this to the fact that the company adapts not only to the needs and interests of employees, and they do not feel the significance of these factors due to their high level of representation in the company. At the same time, the importance of such factors as "Career growth", "Comfortable atmosphere in the team" and "High professional level of colleagues" increases, which reflects the desire of employees to develop, work among "advanced" colleagues in a comfortable environment. As a result, there is a large number of those who are proud to work for this company. (Figure 2)

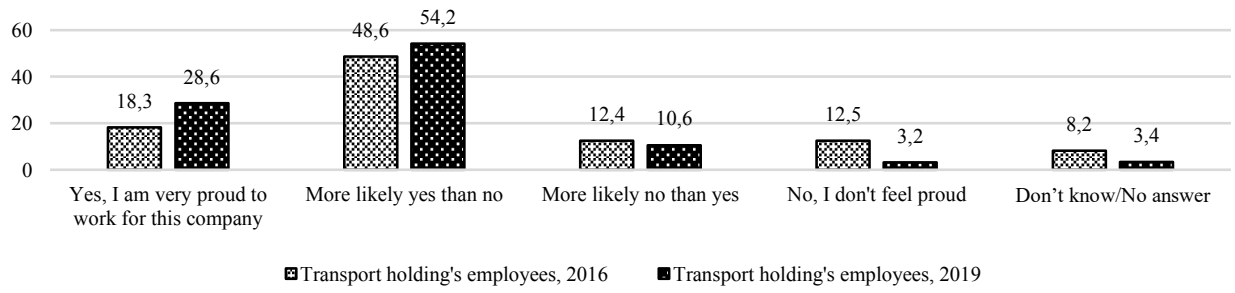

Fig. 2. Distribution of responses to the question "Are you proud to work for this company?", $\%$ of the number of respondents 
In 2019, more than 86 thousand people were trained in the successfully operating corporate university of RZD; more than 150 educational programs of different categories were implemented; the company successfully implements and upgrades existing educational programmes, and introduces courses for employees to learn digital technology. More than 51.5 thousand workers were educated for leading professions, including 32.7 thousand employees who were trained for a profession for the first time, 6.1 thousand employees who were trained under the professional development programs, and 12.7 thousand employees who were trained for a second profession; more than 175.8 thousand people raised their qualifications by taking courses in training centres, technical schools and colleges. [13].

Special attention should be paid to the Quantum Communications project aimed at the development of the high-tech areas. The roadmap of the project was submitted to the Government of the Russian Federation in May 2020 [14]. By the degree of ambition of the tasks to be solved and on condition of their successful completion, the holding will ensure a leading position in the sphere of 'implementation of quantum communications for the digital transformation of the industrial landscape' (G. Goltsman, 2019), which means the ability to determine the direction of technical and technological development at the global level. [15]

However, this requires the company to shape a new worldview in order to achieve its goals and mitigate undesirable social consequences. The rhetoric of managers clearly shows a desire to promote changes from the top: 'offer new solutions, initiate new projects and motivate employees to look at work processes in a new way.' (D. Shakhanov, 2020). At the same time, managers admit that there is a certain amount of conservatism which 'creates additional barriers for a person who wants to change, is ready to take the initiative, take responsibility, or is focused on making the most rapid decisions that the market requires.' (D. Shakhanov, 2019).

A rigid system of innovation implementation, which restricts the initiative of those employees who do not fully fit into the format of the proposed events, where they can express their views on improving work and interaction, is the main area of inconsistency of the corporate interests. In particular, this is due to the fact that the functions of the change management lie with the top management and are not even partially performed at the rest levels of management.

In our opinion, it is more strategically correct to build relationships with employees not from the position of hierarchical distribution of roles, but to provide for more flexible management of linear enterprises by delegating more powers to middle-level and lowerlevel managers, as well as offer an individual approach to career development. Such a step towards managerial freedom opens up the company's prospects for more comprehensive use of the potential of employees and creates conditions for meeting a greater range of employee needs and increasing their satisfaction with the jobs and the company in general. It is important to take into account the features of professional and career paths, as well as the place of professional education in them. $[16,17]$. The choice of profession is based on a high level of remuneration and a guarantee of a stable workplace and does not ensure full involvement of employees in the operational processes, as well as reduces the opportunities for the fulfilment of their labour potential.

It is necessary to take into account the system of values of the young generation representatives of Generation $\mathrm{Z}$ - who are becoming and will be the main labour source in the future. Their priorities include autonomy, independence, and openness to change while respect for tradition ranks the bottom place in their hierarchy of values. Taking into account that the management approach of Russian Railways, JSC is focused on hierarchy, it may cause a significant mismatch of interests in the future. 


\section{Conclusion}

In summary, we would like to note that the company maintains a confident position in implementing its interests in the field of operational work with personnel and solving tactical and strategic tasks by holding a leading position in the provisions of logistics services. The company is a leading employer in Russia and systematically implements successful measures that contribute not only to the stability of the staff but also to a high level of employee satisfaction with their work and the company. It is safe to say that Russian Railways, JSC is a socially responsible company which has achieved a high degree of correlation of corporate interests between the main subjects of organisational interaction.

The issues that are well worth another look include the effectiveness of the implemented innovative measures, incentives for participation of employees and, in particular, the degree of formalism in the development and presentation of projects on the part of employees. It is also important to consider the risk of productivity loss as the powers of executive and operative administration employees are extended on condition of their increased responsibility for their activities and performance results of the department, as well as the active motivation of employees to implement innovations.

\section{References}

1. A.S. Ogorodov, S.Yu. Saranchuk, N.G. Chevtayeva, RUDN Journal of Sociology, 1, 83 (2017)

2. International trends in personnel management - 2020, https://www2.deloitte.com/

3. A.I. Pozmogov, Management Issues, 39 (2019)

4. I.V Naumov, The Manager, 5 (2020)

5. V.A. Sadovnichii, G.V. Osipov, A.A. Akaev, A.S. Malkov, S.G. Shulgin., Mathematical Simulation and Forecast, 14 (2018)

6. J. Fernández-Guadaño, J.H. Sarria-Pedroza , Open Access Journal, 6 (2018)

7. A.Hein, M.Jankovic, W.Feng, R.Farel, J.Yune, B.Yannou. Journal of Cleaner Production, 148 (2017)

8. I.N. Tkachenko, I.V. Pervukhina, A.A. Zlygostev, The Manager, 2 (2020)

9. A.S. Vatoropin, N.G. Chevtaeva, S.A. Vatoropin, Management Issues, 4 (2017)

10. N.G. Chevtayeva, A.S. Vatoropin, The image of the future 2019, Materials of the scientific conference of the XIII Kovalev readings (2019)

11. I.A. Koch, V.A. Orlov, Management issues, 1 (2020)

12. A. Fedorova, 10th International Days of Statistics and Economics (2016)

13. Report on activities in the field of sustainable development (2019), https://company.rzd.ru/

14. A new round of development of quantum communications at Russian Railways: the program was sent to the government, https://digitalrzd.ru/

15. Quantum communications: what is it and why are they Russian Railways need it?, https://www.rzd-partner.ru/

16. O.N. Shestopalova, T.V. Okuneva, Herald of the Ural State University of Railway, 30 (2016)

17. T.V. Okuneva, O.N. Shestopalova, Herald of the Ural State University of Railway, $\mathbf{4 3}$ (2019) 